\title{
TURISMO RURAL: PRODUTOS E SERVIÇOS
}

\section{Ubiratam de Nazareth Costa Pereira ${ }^{1}$}

Resumo: O turismo se constitui em uma importante atividade econômica geradora de empregos, renda, receitas, divisas e impostos, se apresentando como uma atividade multidimensional, multifacetada, que exerce grande influência na vida de pessoas e negócios. Dentre os mais diversos segmentos turísticos existentes, um que tem ganho destaque é o turismo rural sendo relevante o número de propriedades rurais quem tem incluído a atividade turística em suas laborações cotidianas. Isto exposto, o objetivo desse artigo é o de demonstrar as principais modalidades de produtos e ou serviços turísticos oferecidos que podem ser enquadrados como turismo rural. A pesquisa se caracteriza como um trabalho de abordagem exploratório, desenvolvido por meio de um levantamento documental e pesquisa bibliográfica sobre o tema. As atividades turísticas foram subdividias em quatro categorias, abrangendo meios de hospedagem, serviços de alimentação, agroturismo e outros produtos e serviços turísticos desenvolvidos no meio rural.

Palavras-chave: Turismo; Turismo rural; Agroturismo.

\footnotetext{
${ }^{1}$ Professor/Centro Universitário Senac campus Campos do Jordão, Brasil. E-mail: upereira@sp.senac.br.
} 